\title{
Purwarupa Alat Kalibrasi Kerataan Bidang Kerja menggunakan Laser Sensor
}

\author{
BUDI SUGANDI, SURADI WIYONO
}

Teknik Elektro Politeknik Negeri Batam

Email: budi_sugandi@polibatam.ac.id

Received 24 April 2018 | Revised 14 Mei 2018 | Accepted 31 Mei 2018

\begin{abstract}
ABSTRAK
Salah satu elemen teknologi pendukung dari industri manufaktur elektronika adalah mesin Die Attach. Mesin ini digunakan pada proses assembly komponen dengan metode pick and place komponen pada material. Sebagai proses yang penting dalam industri manufaktur, mesin ini memerlukan kalibrasi secara reguler dan tepat yang akan menjadi kunci sukses dari kualitas suatu produksi. Penelitian ini bertujuan membuat suatu purwarupa alat yang digunakan sebagai pengontrol kalibrasi dengan menggunakan laser sensor. Proses kalibrasi dilakukan dengan cara mengukur kerataan titip sisi work holder menggunakan laser sensor. Kerataan didapatkan dengan membandingkan jarak yang terukur oleh laser sensor pada tiap titik uji. Jarak yang sama pada tiap titik uji menunjukkan kerataan dari work holder. Pergerakan laser sensor dikontrol oleh dua buah motor yang bergerak ke arah sumbu $X$ dan $Y$. Alat ini telah diuji dengan mengkalibrasi pada empat sisi work holder. Hasil pengujian kemudian dibandingkan dengan pengukuran manual dan didapatkan error rata-rata pengukuran sekitar $4 \%$.
\end{abstract}

Kata kunci: Laser sensor, kerataan, kalibrasi, die attach machine

\begin{abstract}
One of the element technology supporting an industrial manufacturing is Die Attach machine. This machine is used at component assembly using component pick and place. As an important process, this machine requires regular and precise calibration to support quality of the product. This research aims to build a prototype system using laser sensor which can be used as calibration instrument. The callibration proses was done by measuring the flatness of each side of work holder using laser sensor. The flatness was obtained by comparing the distance of each testing point. The same distance on each testing point represented the flatness of the wrok holder. The movement of laser sensor was controlled by two motors which moved to $X$ and $Y$ axis. The system has been tested to calibrate each side of work holder. The experimental results were then compare with manual measurement and showed the measurement error about 4\%.
\end{abstract}

Keywords: Laser sensor, flatness, callibration, die attach machine. 


\section{PENDAHULUAN}

Proses Die Attach (DA) adalah suatu proses assembly atau pemasangan suatu komponen (die) pada Printed Circuit Board (PCB). Pada proses ini, kinerja dan kapabilitas dari Die Attach Machine (DAM) akan sangat menentukan kualitas produk yang sebagian besar komponennya merupakan material sensitif yang memerlukan kepresisian dan keakuratan tingkat tinggi.

Work Holder (WH) pada DAM adalah bagian utama dari mesin yang berfungsi sebagai penopang material yang akan dijalankan pada proses DA. Sehingga kondisi dari WH ini sangat berpengaruh terhadap kualitas produksi. Kondisi WH yang baik akan menjamin kualitas material yang dijalankan pada mesin serta kelancaran jumlah hasil produksi yang dihasilkan oleh mesin.

Sebagai bagian utama dari mesin, maka pengontrolan terhadap posisi WH sangat diperlukan dengan cara melakukan pengecekan, perawatan dan kalibrasi secara berkala. Beberapa hal penting yang harus diperhatikan pada saat pengontrolan kondisi WH diantaranya kerataan (Flatness), kebersihan dan penggunaan. Dari ketiga hal diatas, prioritas utama yang berhubungan langsung dengan kualitas produksi adalah pengontrolan kerataan pada $\mathrm{WH}$.

Beberapa pengujian dan pemakaian laser sebagai sensor telah dilakukan oleh beberapa penulis untuk beberapa aplikasi yang berbeda. (Ongkodjojo dkk., 2008) telah melakukan perancangan suatu sistem dan algoritma untuk identifikasi obyek tiga dimensi dengan memanfaatkan laser pointer sebagai pembangkit berkas. Mereka berhasil merancang algoritma yang disusun untuk mendapatkan koordinat 3 dimensi obyek dimulai dari kalibrasi bidang referensi dan kamera kemudian dilanjutkan dengan perhitungan persamaan bidang referensi, perhitungan persamaan garis cahaya kamera, perhitungan persamaan bidang laser, dan diakhiri dengan perhitungan titik perpotongan antara garis cahaya kamera yang memotong obyek dengan bidang laser. Sementara itu (Ula dkk., 2015) telah melakukan analisis perbandingan penggunaan laser dan LED sebagai sumber cahaya pada sensor berat berbasis optik. Dari hasil analisa mereka, didapatkan taraf ketelitian pengukuran dengan menggunakan sumber cahaya LED lebih baik dibanding ketelitian pengukuran menggunakan laser.

Sementara untuk pengujian pengkalibrasian kerataan suatu bahan telah dilakukan oleh beberapa peneliti. Diantaranya pengujian yang telah dilakukan untuk mengukur kerataan di industri pembuatan baja (Molleda dkk., 2013). Mereka menggunakan sensor optic untuk mengukur lebar bahan dengan cara memproyeksikan pola cahaya di atas permukaan produk. Mereka juga mereview tentang pentingnya mendesain dan mengembangkan sensor kerataan pada industri pembuatan baja. (Espinosa dkk., 2008) mereview perbandingan teknik kalibrasi pada permukaan pelat. Artikel mereka menampilkan peralatan dan metoda untuk mengkalibrasi kerataan dari permukaan pelat berukuran besar. Mereka menggunakan electronic level, autocollimator dan laser untuk menguji kerataan permukaan pelat. Berdasarkan hasil pengujian, mereka merekomendasikan untuk menggunakan electronic level karena penggunaannya yang mudah dibanding yang lain. Sementara ketiganya mempuyai hasil resolusi yang sama. Dalam artikel lainnya, (Molleda dkk., 2010) melakukan pengujian kerataan dari produk roll menggunakan laser optik dan merekontruksinnya dalam tiga dimensi secara real time. Mereka berhasil merancang sistem yang dapat menyimpan data input kerataan dari plat baja secara real time dan berhasil dievaluasi secara kualitatif dan kuantitatif. (Zhang dkk., 2014) telah melakukan pengujian kalibrasi berdasarkan pergerakan laser sensor pada target stereo. Mereka dapat menanggulangi keterbatasan pengukuran akibat lamanya waktu pemodelan sistem dan 
linearitas pengukuran. Sementara dalam artikel lainnya, (Li, 2008) telah mencoba suatu metoda untuk mengkalibrasi sensor vision dengan dengan struktur garis. Mereka berhasil melakukan kalibrasi dengan cukup akurat. (Choi dkk., 2014) memberikan metode baru dalam mengkalibrasi menggunakan laser sensor 3D. Metode ini dapat mengatasi kekurangan laser sensor 2D dalam mentraking pergerakan. Artikel ini menggunakan metode ortoghonaliti pada bidang normal.

Berdasarkan penelitian dan pengujian yang telah dipaparkan di atas, dalam artikel ini akan dikembangkan suatu purwarupa sistem yang akan digunakan untuk mengontrol kerataan (flatness) pada WH dengan menggunakan laser sensor. Alat ini akan mengkalibrasi flatness atau kerataan bidang kerja (work holder) pada mesin Die Attach. Proses kalibrasi dilakukan dengan cara mengukur kerataan titip sisi work holder menggunakan laser sensor. Laser sensor akan mendeteksi jarak tiap titik uji. Kerataan didapatkan dengan membandingkan jarak yang terukur oleh laser sensor pada tiap titik uji. Jarak yang sama pada tiap titik uji menunjukkan kerataan dari work holder. Pergerakan laser sensor dikontrol oleh dua buah motor yang masing-masing bergerak ke arah sumbu $X$ dan $Y$. Keseluruhan sistem dikontrol oleh mikrokontroler sebagai pusat pemrosesan datanya. Dengan sistem pengukuran kerataan secara otomatis ini, maka akan mengurangi pekerjaan konvensional yang dilakukan dengan pengukuran menggunakan alat ukur semisal penggaris. Selain itu dari sisi kepresisian dan keakuratan hasil pengukuran akan lebih objektif karena tidak tergantung pembacaan manual oleh mata manusia sehingga akan mengefisienkan waktu kalibrasi kerataan dan dapat menghasilkan tingkat kerataan yang lebih presisi dan akurat.

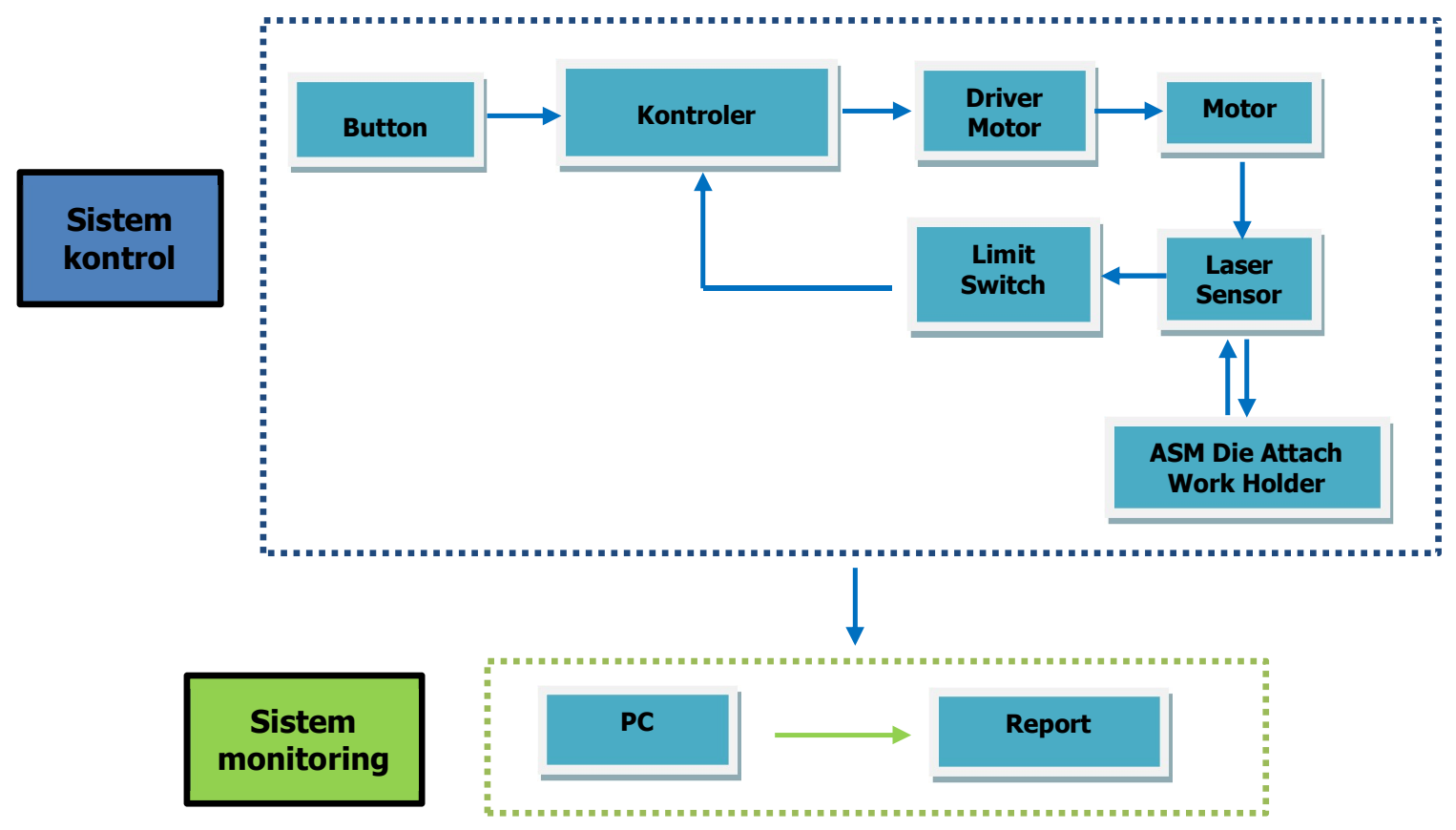

Gambar 1. Blok Diagram Sistem

Untuk memudahkan pembahasan, artikel ini disusun sebagai berikut. Dalam bagian 2, akan dijelaskan metodologi yang digunakan dalam merancang sistem secara keseluruhan. Mulai dari perancangan mekanik, perancangan modul kontrol dan pengujian sensornya. Dalam bagian 3, akan dipaparkan perbandingan hasil pengukuran kerataan yang diuji secara manual dan otomatis. Dalam bagian ini pun akan dibahas pula analisa hasil pengujian yang 
telah dilakukan. Kesimpulan dan beberapa saran untuk perbaikan sistem ke depan disajikan dalam bagian 4.

\section{METODOLOGI PENELITIAN}

Gambar 1 menunjukkan blok diagram sistem keseluruhan dalam pendeteksian kerataan WH menggunakan laser sensor. Proses kalibrasi diawali dengan pendeteksian jarak WH menggunakan laser sensor. Laser sensor akan memberikan sinyal yang ditransmisikan ke WH dan dipantulkan kembali ke laser sensor. Dari transmisi dan pantulan sinyal tadi akan didapatkan jarak laser sensor terhadap WH. Jarak ini kemudian akan diolah sebagai input oleh bagian pengendali dan akan ditampilkan hasilnya pada tampilan LCD yang merupakan modul bawaan I2C yang digunakan sebagai tampilan keluaran hasil deteksi laser sensor.

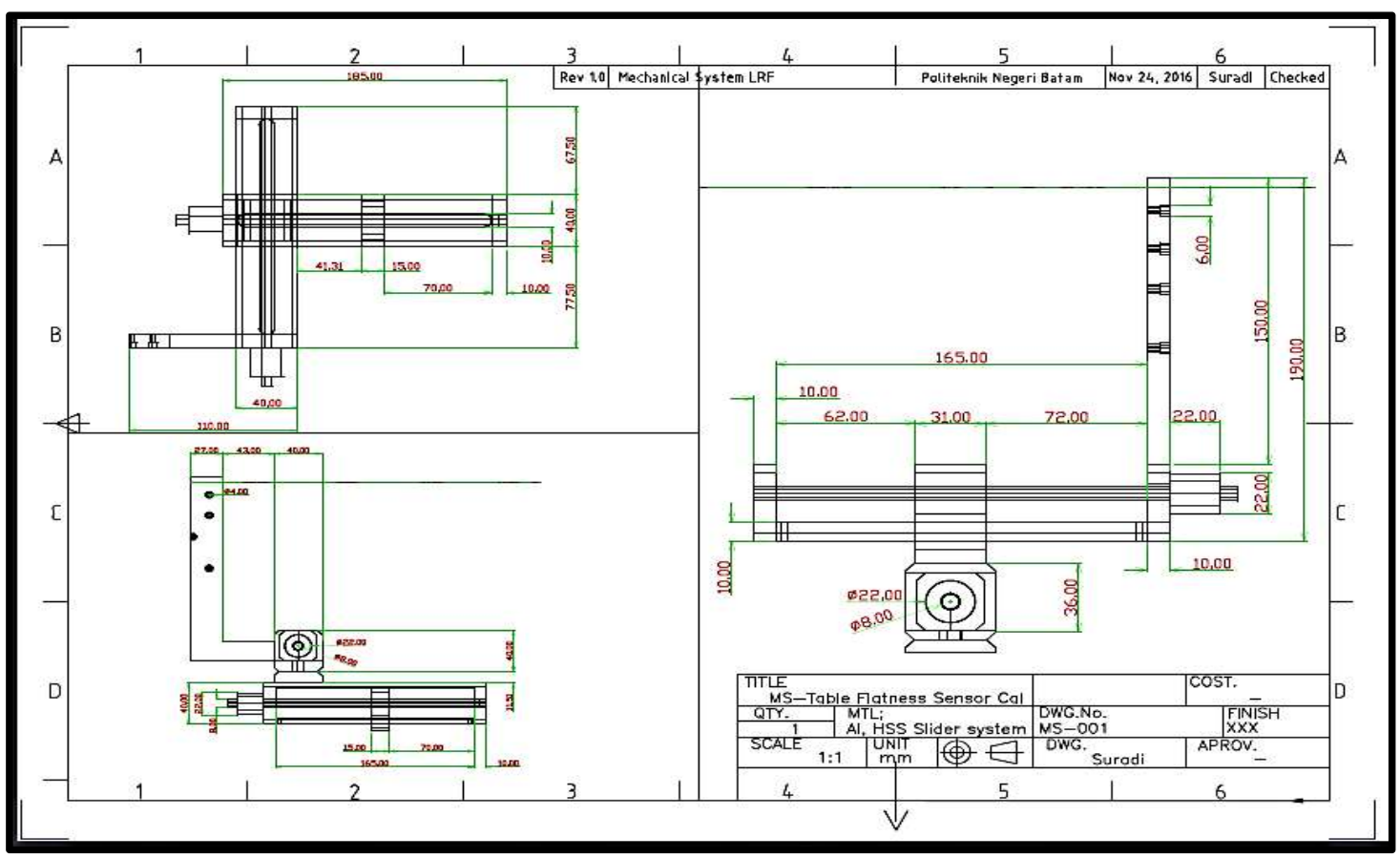

Gambar 2. Rancangan Mekanik Sistem

Untuk menggerakkan laser sensor ke empat titik pengujian, sistem dilengkapi dengan dua buah motor yang dapat bergerak pada dua sumbu yaitu sumbu $\mathrm{X}$ dan $\mathrm{Y}$. Motor ini masingmasing digerakan oleh driver motor yang dikontrol oleh pengendali. Untuk membatasi gerakan motor pada kedua sumbu $X$ dan $Y$ digunakan empat buah limit switch sebagai penanda awal dan akhir pergerakan. Keempat limit switch tersebut menjadi masukan bagi kontroler untuk mengatur pergerakan motor. Sistem dilengkapi juga dengan 3 buah tombol yaitu tombol Start, Stop dan Reset. Tombol Start berfungsi untuk memulai kalibrasi sedangkan tombol Stop berfungsi untuk menghentikan proses kalibrasi. Sementara tombol Reset berfungsi untuk mereset hasil kalibrasi dan akan mengembalikan posisi laser sensor pada posisi awal. Selain itu, dilengkapi juga dengan 1 buah Buzzer sebagai alarm untuk notifikasi salah satu proses yang telah selesai dilakukan.

Rancangan mekanik didesain menggunakan perangkat lunak AutoCAD seperti ditunjukkan pada Gambar 2. Desain mekanik dilakukan dengan mempertimbangkan beberapa hal diantaranya pergerakan kedua motor pada arah sumbu X dan Y. Untuk menggerakkan laser 
sensor kearah sumbu $X$ dan $Y$ tersebut digunakan logam berulir, sehingga setiap putaran motor akan membawa laser sensor mendekat atau menjauh dari titik referensi. Dimensi alat yang dibuat berukuran $20 \mathrm{~cm} \times 20 \mathrm{~cm} \times 20 \mathrm{~cm}$. Dari dimensi alat tersebut, maka tinggi maksimum yang bisa dideteksi oleh laser sensor adalah $19 \mathrm{~cm}$.

Diagram pengawatan dari sistem laser sensor yang akan dibuat ditunjukan pada Gambar 3. Beberapa komponen yang digunakan adalah sensor Parallax Laser Range Finder (LRF) sebagai laser sensor (Akizukidenshi, 2017), modul kontrol Arduino Mega 2560 (Arduino, 2017), motor driver Monster Moto Shield untuk mengatur kecepatan dan torsi motor, motor DC, modul LCD, beberapa limit switch dan tombol serta buzzer .

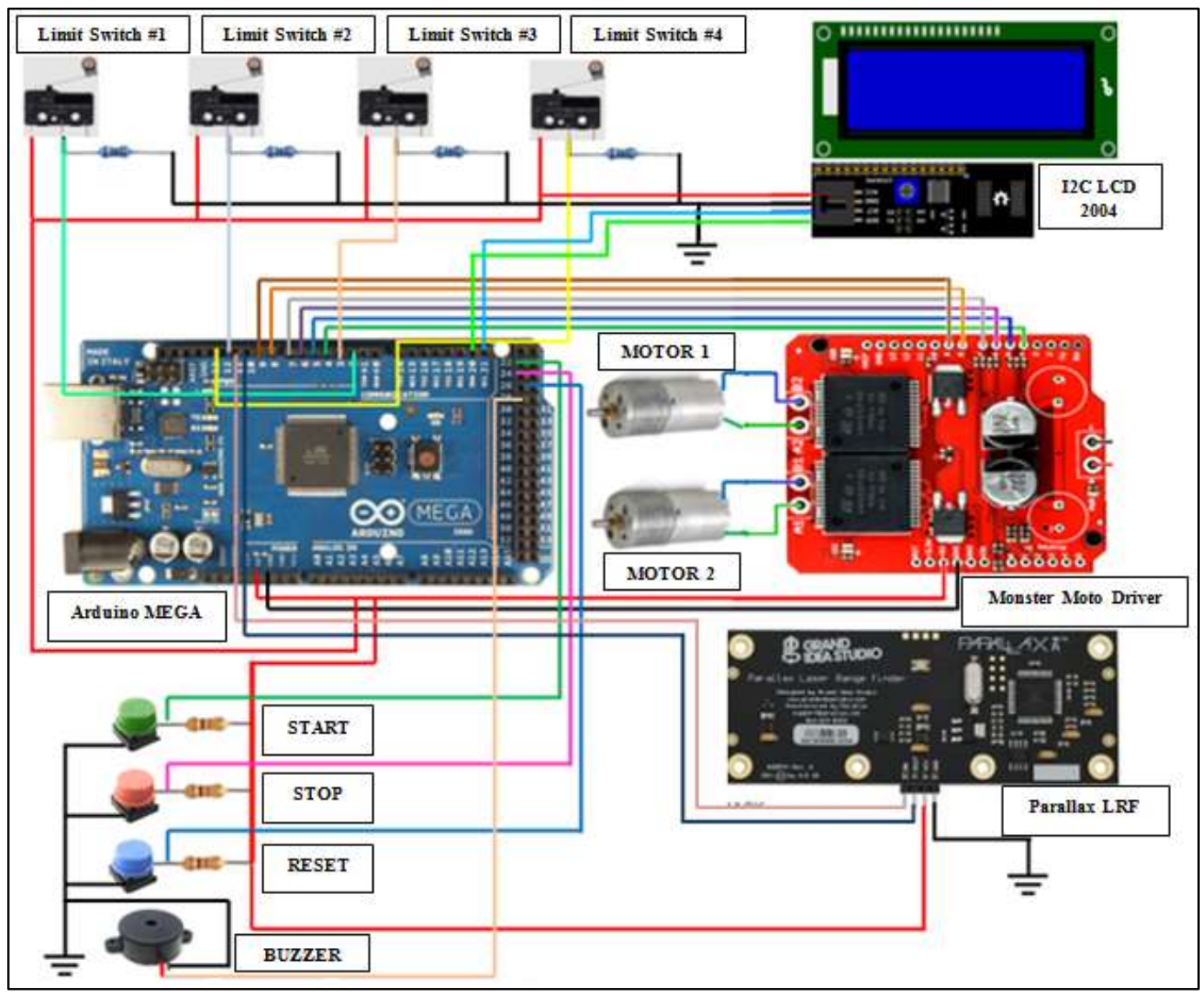

Gambar 3. Diagram Sistem Perancangan Laser Sensor

Diagram koneksi laser sensor dengan kontroler dapat dilihat pada Gambar 4. Dari Gambar 4 terlihat bahwa LRF terkoneksi dengan mikrokontroler Arduino Mega 2560 melalui keempat pin dengan konfigurasi Ground (GND), VCC , Sin dan Sout. Pin Sin dihubungkan dengan pin Digital I/O 11 sebagai Transmitter (Tx) serta pin Sout dihubungkan dengan pin Digital I/O 10 sebagai Receiver (Rx).

PC sendiri sebagai pengolah data terhubung dengan kabel USB menggunakan program Arduino Microcontroller IDE. Program yang diunggah ke mikrokontroler dapat dijalankan langsung pada sistem, sehingga sistem dapat bekerja otomatis. Jika terjadi error atau sistem bekerja tidak sesuai dengan keinginan, maka sistem dapat kembali diprogram ulang dan diunggah ulang dan begitu seterusnya sehingga didapatkan hasil yang paling optimal. Sistem yang dibuat merupakan sistem portable yang dapat digunakan di line produksi manapun pada saat akan mengkalibrasi WH tanpa harus terhubung dengan PC. 


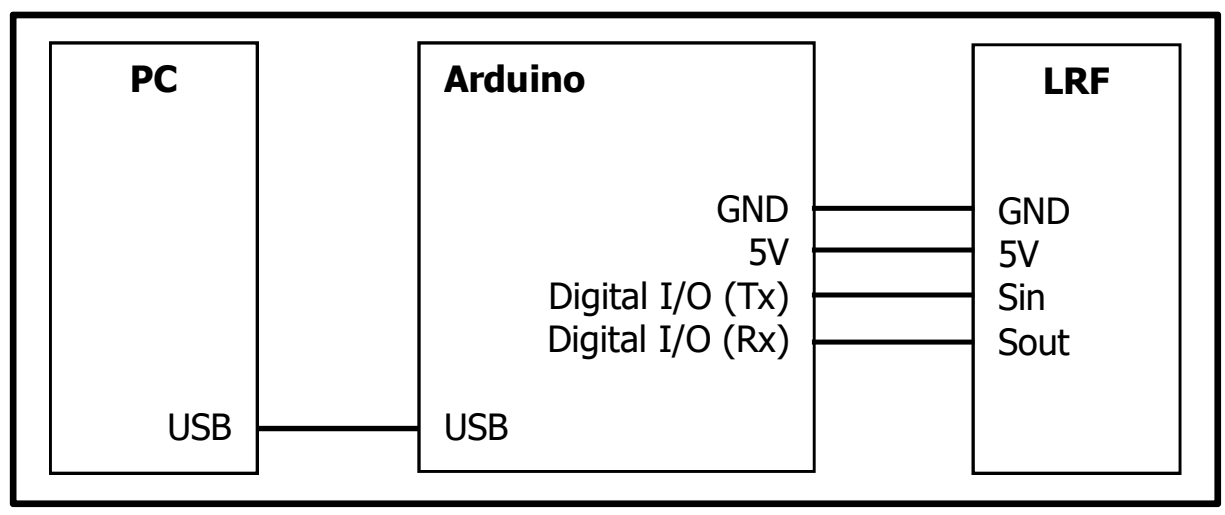

\section{Gambar 4. Diagram Hubungan antar Pin pada Pengendali dengan Laser Sensor}

Perancangan sistem perangkat lunak didesain berdasarkan diagram alir yang ditunjukkan pada Gambar 5. Proses kalibrasi kerataan WH diawali dengan pembacaan titik awal pergerakan oleh laser sensor. Di masing-masing titik uji ditempatkan limit switch sebagai penanda bagi kontroler untuk mengirimkan sinyal ke driver motor untuk menghentikan motor dan juga memberikan sinyal ke laser sensor untuk mentransmisikan sinyal ke titik uji dan menerima sinyal pantulan dari titik uji tersebut.
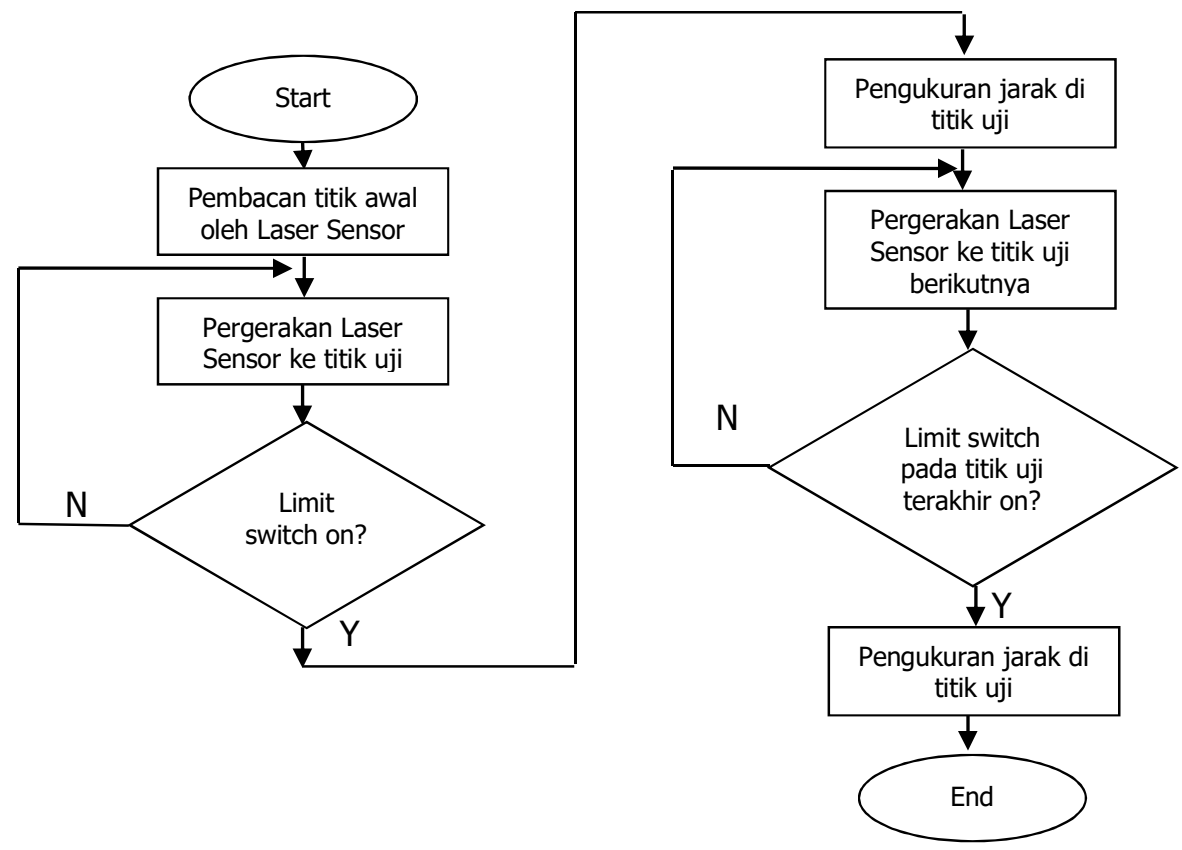

Gambar 5. Diagram Alir Sistem 
Selanjutnya pengendali mengolah data tersebut sebagai jarak terukur dari laser sensor ke titik uji. Hasil pengukurannya kemudian diinput kontroler untuk ditampilkan pada LCD sehingga terbaca sebagai jarak sesungguhnya. Setelah melakukan pengukuran di satu titik uji, maka kontroler akan mengirimkan sinyal ke driver motor untuk menggerakkan motor ke titik uji yang kedua. Motor bergerak ke titik uji yang dibatasi oleh limit switch sebagai penanda titik uji. Laser sensor akan mentransmisikan sinyal di titik uji tersebut dan menerima sinyal pantulannya, yang kemudian dioleh oleh kontroler sebagai jarak antara laser sensor dengan WH. Demikian selanjutnya kontroler akan mengirimkan sinyal ke driver motor untuk menggerakkan motor ke masing-masing titik uji sampai pada titik uji yang terakhir. Jarak yang terbaca di masing-masing titik uji kemudian dibandingkan untuk melihat kerataan dari WH. Dari data tersebut dapat diketahui tingkat kerataan dari WH dan juga keakuratan pengukuran WH secara otomatis menggunakan laser sensor.

\section{HASIL DAN PEMBAHASAN}

Sebelum dilakukan pengukuran terhadap kerataan $\mathrm{WH}$, terlebih dahulu dilakukan pengujian terhadap laser sensor itu sendiri. Selanjutnya dilakukan pengukuran secara manual sebagai pembanding atau referensi bagi pengukuran otomatis menggunakan laser sensor.

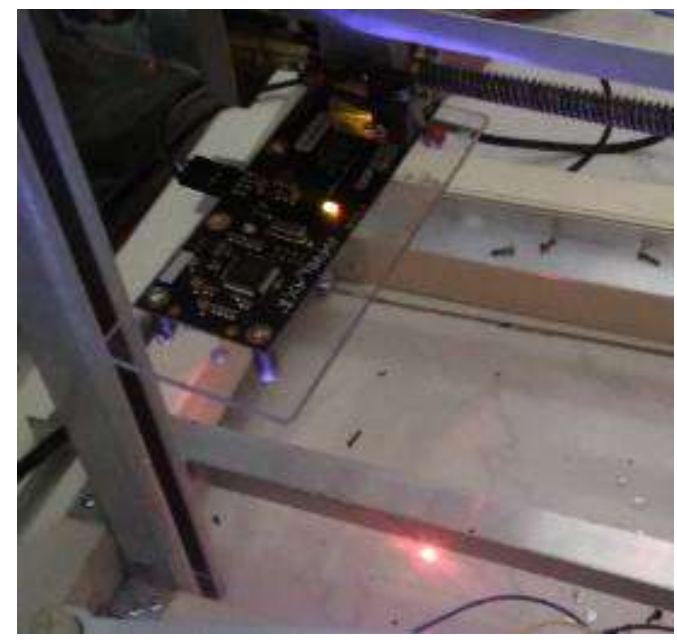

Gambar 6. Proses Pengujian Laser Sensor

Tahap pertama adalah pengujian terhadap laser sensor. Pada proses ini, dilakukan pengujian laser sensor dengan cara menghubungkan sensor ke pengendali seperti yang ditunjukkan pada Gambar 6. Pengujian dilakukan dengan tes pembacaan sensor menggunakan perintahperintah seperti dijelaskan detail dalam datasheet laser sensor (Akizukidenshi, 2017). Proses pembacaan yang dilakukan adalah proses pembacaan lamanya waktu sinyal ditransmisikan oleh laser sensor dan diterima kembali. Proses pembacaan ini oleh kontroler diolah dan diproses menjadi jarak antara laser sensor dengan $\mathrm{WH}$.

Tahap kedua adalah proses pengukuran manual jarak menggunakan penggaris. Proses ini dijadikan sebagai referensi keakuratan hasil pengukuran otomatis. Untuk simulasi pengukuran digunakan sampel WH menggunakan kertas karton. 
Pengukuran dilakukan berdasarkan peta posisi titik deteksi laser sensor pada karton. Data jarak diambil pada tiap titik uji seperti yang terlihat pada Gambar 7. Pemilihan 4 titik uji pada tiap sisi WH dilakukan dengan asumsi jika jarak 4 sisi ini sama, maka posisi WH dikatakan dalam keadaan rata. Laser sensor digerakan pada tiap titik uji kemudian diukur jarak antara laser sensor dengan WH. Pengukuran dilakukan sebanyak 30 kali untuk tiap titik pengujian. Data yang diperoleh tersaji dalam Tabel 1.

Tabel 1. Hasil Pengukuran Manual

\begin{tabular}{|c|c|c|c|c|}
\hline No & Titik A & Titik B & Titik C & Titik D \\
\hline 1 & 176 & 175 & 171 & 174 \\
\hline 2 & 174 & 173 & 172 & 174 \\
\hline 3 & 174 & 175 & 172 & 173 \\
\hline 4 & 175 & 175 & 172 & 174 \\
\hline 5 & 175 & 174 & 171 & 173 \\
\hline 6 & 176 & 174 & 173 & 173 \\
\hline 7 & 174 & 174 & 172 & 174 \\
\hline 8 & 174 & 173 & 173 & 173 \\
\hline 9 & 175 & 175 & 172 & 174 \\
\hline 10 & 174 & 175 & 171 & 174 \\
\hline 11 & 176 & 174 & 171 & 173 \\
\hline 12 & 176 & 173 & 172 & 173 \\
\hline 13 & 176 & 174 & 172 & 172 \\
\hline 14 & 175 & 174 & 171 & 173 \\
\hline 15 & 175 & 174 & 173 & 174 \\
\hline 16 & 174 & 175 & 172 & 174 \\
\hline 17 & 175 & 174 & 172 & 173 \\
\hline 18 & 175 & 175 & 172 & 172 \\
\hline 19 & 176 & 174 & 171 & 173 \\
\hline 20 & 175 & 174 & 172 & 174 \\
\hline 21 & 176 & 175 & 171 & 173 \\
\hline 22 & 174 & 175 & 173 & 173 \\
\hline 23 & 174 & 174 & 172 & 174 \\
\hline 24 & 176 & 175 & 172 & 174 \\
\hline 25 & 176 & 175 & 171 & 174 \\
\hline 26 & 176 & 175 & 172 & 173 \\
\hline 27 & 175 & 174 & 172 & 173 \\
\hline 28 & 175 & 175 & 173 & 174 \\
\hline 29 & 174 & 174 & 171 & 173 \\
\hline 30 & 175 & 175 & 171 & 174 \\
\hline Min & 174 & 173 & 171 & 172 \\
\hline Max & 176 & 175 & 173 & 174 \\
\hline Ave & 175 & 174 & 172 & 173 \\
\hline $\begin{array}{l}\text { Std. } \\
\text { dev }\end{array}$ & 0.809 & 0.702 & 0.699 & 0.621 \\
\hline
\end{tabular}

Dari data pengukuran manual di atas dapat dihitung jarak rata-rata sebagai berikut :

$$
\text { jarak rata }- \text { rata }=\sum_{k=1}^{4} \text { jarak rata }- \text { rata tiap titik } / 4
$$

Dengan menggunakan Persamaan 1 di atas didapatkan jarak rata-rata pengukuran manual adalah $(175+174+172+173) / 4=173,5 \mathrm{~mm}$ atau dibulatkan $174 \mathrm{~mm}$. 


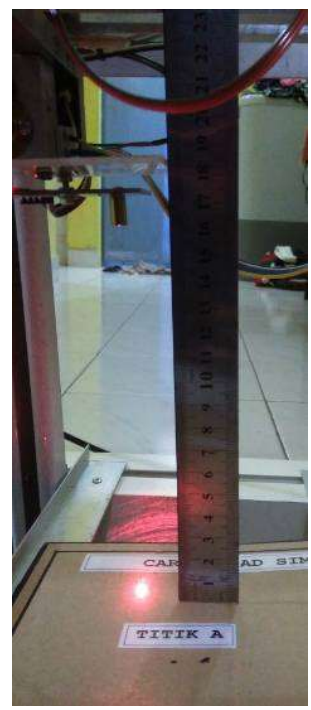

titik A

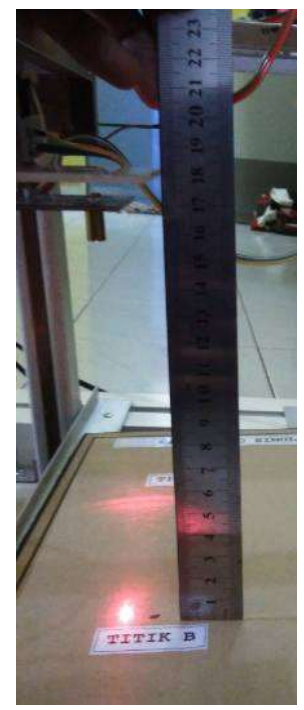

titik B

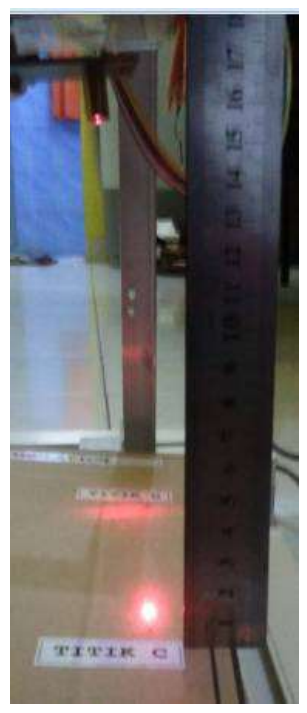

titik C

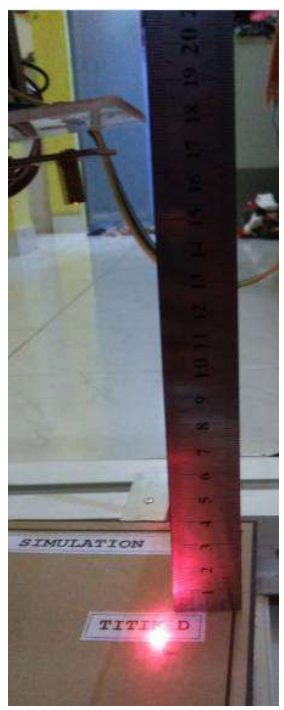

titik D

Gambar 7. Proses Pengukuran Manual dengan Penggaris pada Empat Titik Uji

Tahap ketiga adalah proses pengukuran otomatis menggunakan sistem yang telah dibangun. Proses pengukuran dilakukan seperti pengukuran manual dengan cara menggeserkan laser ke masing-masing titik uji. Data jarak diambil pada tiap titik uji seperti yang terlihat pada Gambar 8. Pengukuran dilakukan sebanyak 30 kali untuk tiap titik pengujian. Data pengukuran diolah oleh pengendali dan ditampilkan di LCD. Hasil pengukuran yang diperoleh tersaji dalam Tabel 2.

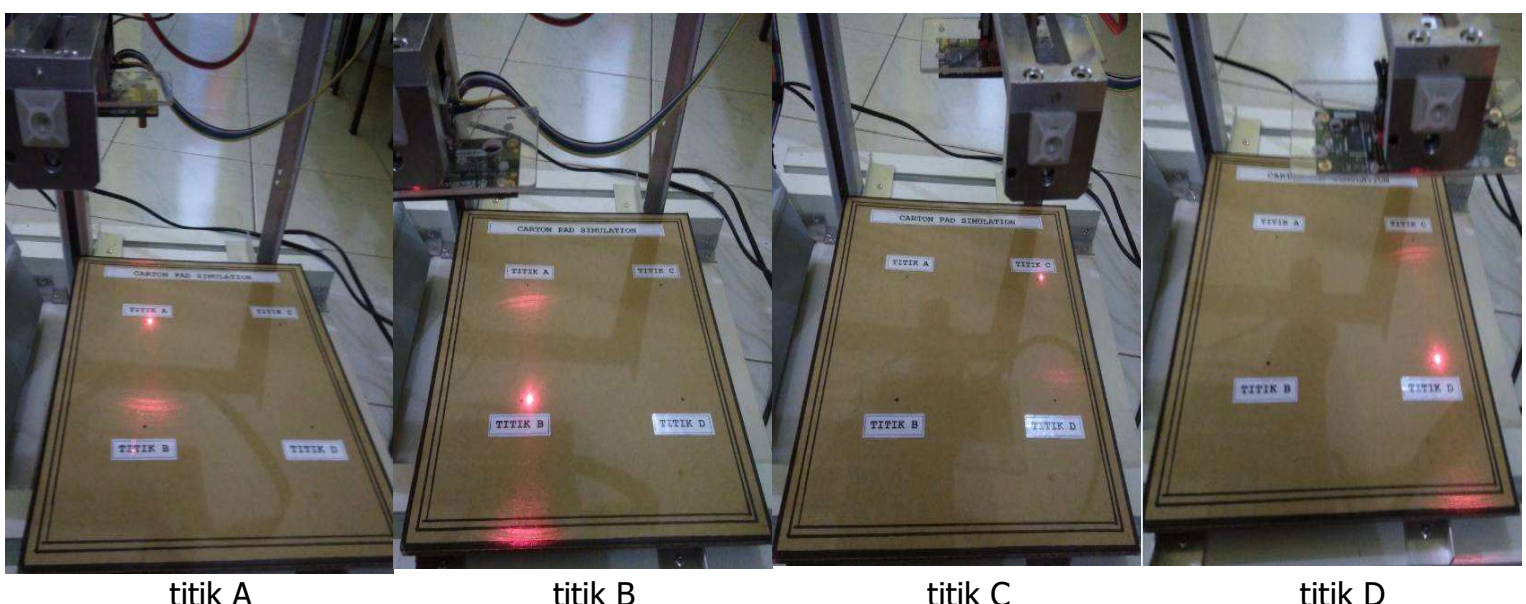

Gambar 8. Proses Pengukuran Otomatis Menggunakan Laser Sensor pada Tiap Titik Uji

Dari Tabel 2, pengukuran jarak rata-rata pengukuran otomatis berdasarkan Persamaan (1) adalah $(182+180+180+181) / 4=180,75 \mathrm{~mm}$ atau dibulatkan $181 \mathrm{~mm}$. 
Dengan membandingkan hasil rata-rata pengukuran manual dan otomatis maka didapatkan error pengukuran menggunakan Persamaan 2 sebagai berikut :

$$
\text { Error }=\frac{181-174}{181} * 100 \%=4 \%
$$

Error pengukuran ini masih dalam toleransi spesifikasi error dari laser sensor sepeti tertera dalam data sheet komponen yaitu error $<5 \%$.

Tabel 2. Hasil Pengukuran dengan Laser Sensor

\begin{tabular}{|c|c|c|c|c|}
\hline No & Titik A & Titik B & Titik C & Titik D \\
\hline 1 & 183 & 180 & 178 & 180 \\
\hline 2 & 182 & 178 & 178 & 179 \\
\hline 3 & 182 & 182 & 179 & 181 \\
\hline 4 & 182 & 181 & 179 & 179 \\
\hline 5 & 181 & 177 & 181 & 180 \\
\hline 6 & 181 & 179 & 179 & 179 \\
\hline 7 & 183 & 178 & 178 & 181 \\
\hline 8 & 183 & 180 & 178 & 183 \\
\hline 9 & 183 & 179 & 178 & 183 \\
\hline 10 & 183 & 181 & 181 & 181 \\
\hline 11 & 182 & 183 & 181 & 181 \\
\hline 12 & 182 & 179 & 179 & 181 \\
\hline 13 & 184 & 179 & 180 & 181 \\
\hline 14 & 184 & 179 & 180 & 181 \\
\hline 15 & 181 & 179 & 181 & 180 \\
\hline 16 & 181 & 180 & 179 & 181 \\
\hline 17 & 181 & 180 & 179 & 179 \\
\hline 18 & 182 & 180 & 179 & 181 \\
\hline 19 & 181 & 180 & 179 & 181 \\
\hline 20 & 182 & 179 & 181 & 182 \\
\hline 21 & 182 & 181 & 180 & 183 \\
\hline 22 & 181 & 183 & 179 & 183 \\
\hline 23 & 181 & 183 & 180 & 181 \\
\hline 24 & 181 & 179 & 172 & 182 \\
\hline 25 & 183 & 181 & 181 & 181 \\
\hline 26 & 182 & 181 & 180 & 181 \\
\hline 27 & 181 & 181 & 179 & 181 \\
\hline 28 & 184 & 181 & 180 & 181 \\
\hline 29 & 183 & 179 & 181 & 181 \\
\hline 30 & 183 & 179 & 179 & 183 \\
\hline Min & 181 & 177 & 178 & 179 \\
\hline Max & 184 & 183 & 181 & 183 \\
\hline Ave & 182 & 180 & 180 & 181 \\
\hline $\begin{array}{l}\text { Std. } \\
\text { dev }\end{array}$ & 1.008 & 1.509 & 1.042 & 1.258 \\
\hline
\end{tabular}

Dari pengukuran manual dan otomatis, maka kita dapat menentukan batas spesifikasi pengukuran terendah (Lower Spec Limit (LSL)) dan batas spesifikasi pengukuran tertinggi (Upper Spec Limit (USL)) seperti yang ditunjukkan dalam Persamaan (3) dan Persamaan (4).

$$
L S L=174-(4 \% \times 174)=167 \mathrm{~mm}
$$




$$
U S L=181+(4 \% \times 181)=188 \mathrm{~mm}
$$

Dengan menggunakan nilai LSL dan USL pada Persamaan (3) dan Persamaan (4), maka kita dapat menentukan dan menganalisa kemampuan laser sensor dengan menggunakan Minitab Statistical Software seperti terlihat dalam Gambar 9. Before menunjukkan pengukuran manual sedangkan after menunjukan pengukuran otomatis.

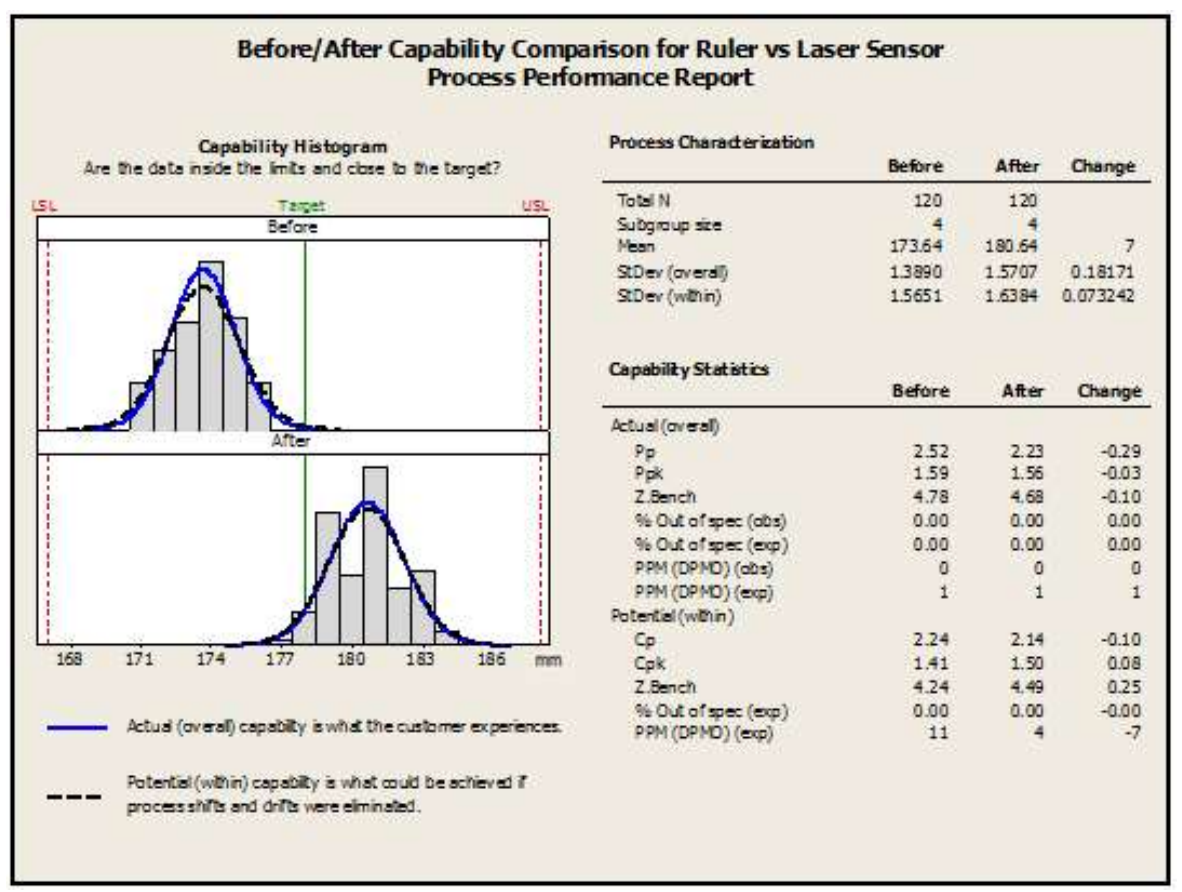

Gambar 9. Grafik Analisis Hasil Pengukuran

Dari Gambar 9 dapat dianalisa beberapa hal, diantaranya yaitu :

1. StDev overall pada pengukuran manual (Ruler) adalah sebesar 1.389 , sedangkan pengukuran otomatis dengan laser sensor sebesar 1.570, artinya standar deviasi atau sebaran data dari pengukuran secara otomatis lebih bervariasi daripada pengukuran manual.

2. Ppk (Process performance) pengukuran manual sebesar 2.52 sedangkan pengukuran otomatis sebesar 2.23, artinya data pengukuran manual memiliki indikator kelebihan sebesar 0.29. Kinerja proses manual masih lebih baik dari otomatis.

3. Cpk (Capability Process) atau kehandalan proses pengukuran manual adalah 1.41 sedangkan pengukuran otomatis adalah 1.50. Nilai Cpk diatas 1.33 secara statistika adalah Capable, seperti dijelaskan di dalam datasheet Minitab Statistical Software. Sehingga, kedua hasil pengukuran ini dapat digunakan sebagai alat pengukuran flatness atau kerataan suatu obyek. Akan tetapi, nilai Cpk pengukuran otomatis lebih tinggi dibanding pengukuran manual yang berarti pengukuran otomatis lebih handal dibanding pengukuran manual.

4. Tidak ada data yang Out of Spec atau keluar melebihi batas atas (UCL) maupun batas bawah (LCL).

Dari 4 kriteria, purwarupa sistem pengukuran menggunakan laser sensor masih dalam range sebagai sistem yang dapat digunakan sebagai alat pengukur kerataan $\mathrm{WH}$, meskipun masih ada beberapa kekurangan dibanding pengukuran manual. 


\section{KESIMPULAN}

Dari hasil pengujian dan pengukuran serta analisis yang telah dilakukan, maka dapat disimpulkan beberapa point sebagai berikut:

1. Sistem yang dibangun telah menunjukan hasil yang memenuhi ekpektasi keakuratan dan kepresisian dalam melakukan pengkalibrasian kerataan $\mathrm{WH}$.

2. Dari hasil pengujian alat terhadap empat titik uji didapatkan error pengukuran sebesar $4 \%$ yang masih dalam batas spesifikasi error dari alat uji sesuai dengan yang tertera dalam data sheet komponen.

3. Hasil penghitungan kehandalan pengukuran menunjukkan bahwa sistem ini mempunyai kehandalah lebih dibanding sistem manual. Sistem ini dapat diaplikasikan lebih lanjut untuk mengkalibrasi kerataan WH yang lain.

4. Dari hasil pengujian, akurasi sistem ini sangat dipengaruhi oleh pergerakan motor dari satu titik uji ke titik uji yang lain. Fluktuasi hasil pengukuran yang masih besar disebabkan oleh pergerakan motor yang belum stabil yang berimbas pada hasil pengukuran yang kurang akurat.

5. Untuk kestabilan pergerakan motor yang lebih baik disarankan untuk merancang sistem mekanik yang kokoh yang dapat menopang pergerakan motor menjadi lebih stabil, sehingga akan didapatkan kepresisian dan keakurasian alat yang lebih baik.

\section{DAFTAR RUJUKAN}

Ongkodjojo, S., Adipranata, R., Oentaryo, A., Mesin, J. T., \& Petra, F. (2008). System and Algorithm Design of 3 Dimensional Object Identification use Laser Pointer as Beam Generator. Seminar Nasional Teknik Mesin.

Ula, R. K., Hanto, D., \& Widiyatmoko, B. (2015). Analisis Perbandingan Penggunaan LASER dan LED sebagai Sumber Cahaya pada Sensor Berat Berbasis Optik. Prosiding Seminar Nasional Fisika 2015, (pp. 323-326).

Molleda, J., Usamentiaga, R., \& García, D. F. (2013). On-line flatness measurement in the steelmaking industry. Sensors (Switzerland), 13(8), 10245-10272. https://doi.org/10.3390/s130810245

Espinosa, S. O., Espinosa, A. O. C., Diaz, P. J., Baca, M. C., \& Allison, B. N. (2008). Comparison of Calibration Methods for a Surface Plate. International Workshop and Sysposium.

Molleda, J., Usamentiaga, R., Garcia, F. D., \& Bulnes, F. (2010). Real-time flatness inspection of rolled products based on optical laser triangulation and three-dimensional surface reconstruction. Journal of Electronic Imaging - J ELECTRON IMAGING, 19.

Zhang, J., Sun, J., Liu, Z., \& Zhang, G. (2014). A flexible calibration method for laser displacement sensors based on a stereo-target. Measurement Science and Technology, 25(10). https://doi.org/10.1088/0957-0233/25/10/105103

Li, Z. (2008). Accurate calibration method for a structured light system. Optical Engineering, 4オ5), 053604. https://doi.org/10.1117/1.2931517 
Choi, D. G., Bok, Y., Kim, J. S., \& Kweon, I. S. (2014). Extrinsic calibration of 2D laser sensors. In 2014 IEEE International Conference on Robotics and Automation (ICRA) (pp. 3027-3033). https://doi.org/10.1109/ICRA.2014.6907295

Akizukidenshi. (2017). Data sheet Laser sensor Finder. Retrieved from //akizukidenshi.com/download/ds/parallax/LaserRangeFinder-v1.0.pdf

Arduino. (2017). Tutorial Arduino Mega 2560. Retrieved from https://www.arduino.cc/en/Guide/ ArduinoMega2560" 